ACTA UNIVERSITATIS LODZIENSIS

FOLIA LITTERARIA POLONICA 1(31) 2016

http://dx.doi.org/10.18778/1505-9057.31.13

Marek Kochan*

\title{
Biznes jako wojna. Retoryka wojenna w tytułach prasy ekonomicznej
}

\author{
Metafora jako narzędzie opisu świata
}

Metafory towarzyszą nam na co dzień, tyleż w codziennej komunikacji, ile w mediach. Trudno się bez nich obyć, tym bardziej, że wiele z nich to metafory zleksykalizowane, uznawane za całkowicie naturalny sposób opisywania określonych zjawisk. Być może dlatego, jak piszą George Lakoff i Mark Johnson, „dla większości ludzi metafora jest środkiem wyobraźni poetyckiej i ozdobą retoryczną, a więc czymś niezwykłym, co w języku codziennym się nie pojawia"1. Metafora jest jednak czymś więcej niż poręczną konstrukcją służącą do przedstawiania rzeczywistości, jej funkcje wykraczają znacznie poza opis: „Istotą metafory jest rozumienie i doświadczanie pewnego rodzaju rzeczy w terminach innej rzeczy"2. Rozumienie i doświadczanie ma też wpływ na działanie jednostki. Konstruując w określony sposób obrazy obiektów, człowiek może zmieniać nastawienie względem tych obiektów - wybierając inne modele adekwatnego w takiej sytuacji zachowania. Obrazy te są ponadto czymś całościowym, nie zaś tylko impresją. Użycie metafory pociąga za sobą konieczność używania pasujących do niej słów, układających się w pojęciową siatkę. Lakoff i Johnson pokazują to na przykładzie metafory „argumentowanie jako wojna”, w której można odnaleźć więcej elementów obrazu służącego do opisania zupełnie innego zjawiska. Skoro to wojna, to mówi się o obronie, atakowaniu, można wygrać, pokonać przeciwnika itp. ${ }^{3}$ Być może gdybyśmy do opisu dyskusji częściej używali np. metafory tańca, wpłynęłoby to znacząco na ich przebieg, skupiając uwagę na warstwie estetycznej, nie

\footnotetext{
* Dr, e-mail: Marek.Kochan@swps.edu.pl; wykładowca w Instytucie Dziennikarstwa Uniwersytetu Warszawskiego (00-927 Warszawa, ul. Nowy Świat 69) oraz na Wydziale Nauk Humanistycznych i Społecznych Uniwersytetu SWPS (03-815 Warszawa, ul. Chodakowska 19/31).

${ }^{1}$ G. Lakoff, M. Johnson, Metafory w naszym życiu, przeł. T. Krzeszowski, PIW, Warszawa 1988, s. 25.

${ }^{2}$ Tamże, s. 27.

${ }^{3}$ Tamże.
} 
zaś na konfrontacji pomiędzy argumentującymi. Autorzy zajmujący się metaforami zauważają daleko idący wpływ używanych metafor na zachowanie człowieka. Metafory „dodają sił, mogą wzbogacać i rozszerzać nasze doświadczenia, ułatwiać konstruktywne podejście do problemów i życiowych wyzwań” lub „mogą ograniczać, odbierać siły, prowokować do negatywnych reakcji i działań”’".

Nie jest przypadkiem, że o metaforze jako o środku perswazji wspominali znawcy retoryki, tacy jak Cyceron i Kwintylian. Z podobnych powodów jak w starożytności stosuje się w retoryce metafory i dziś. Odwołania do skonwencjonalizowanych metafor zapewniają tekstowi obrazowość i zarazem komunikatywność, służą sterowaniu percepcją odbiorcy i narzucaniu mu punktu widzenia nadawcy, pozwalając na ekspozycję i ukrywanie określonych treści, a także proste wyjaśnianie złożonych zjawisk. Wreszcie, poprzez metafory nadawca przekazuje oceny i narzuca odbiorcom określoną perspektywę aksjologiczną ${ }^{5}$.

Metaforyczny opis jakiegoś zjawiska może być też traktowany jako opowieść. Jak twierdzą psychologowie, nasze poznanie i rozumienie świata w ogóle opiera się na narracjach, poprzez które przyswajamy rzeczywistość - tego, co nas spotyka doświadczamy jako historii i tak też zapamiętujemy ${ }^{6}$. Stąd proste opowieści budowane na bazie metafor mogą służyć wyjaśnianiu określonych zjawisk - a tym samym i perswazji.

\section{Funkcje tytułów prasowych}

Niniejszy tekst dotyczy użycia pewnej metafory w tytułach prasowych. Wypada więc teraz poświęcić nieco uwagi funkcjom tytułów, by potem skonfrontować oczekiwania wobec tych krótkich tekstów z ich praktyczną realizacją.

Jak pisze Stanisław Gajda, tytuły prasowe spełniają trzy zasadnicze funkcje: 1) nominatywną (nazywanie tekstu), 2) deskryptywną (przedstawienie treści tekstu) oraz 3) pragmatyczną (oddziaływanie na odbiorcę) $)^{7}$. A więc, krótko rzecz ujmując, łączą opis treści z zachęcaniem do lektury8. Stąd „dobry tytuł to tytuł przykuwający uwagę, zwięzły i oddziałujący na emocje, ale jednocześnie jasno opi-

${ }^{4}$ J. Maciuszek, Metafora jako forma komunikacji perswazyjnej, [w:] Sztuka perswazji, red. R. Garpiel, K. Leszczyńska, Zakład Wydawniczy „Nomos”, Kraków 2004, s. 117-118.

${ }^{5}$ T. Dobrzyńska, Metafory wartościujace w publicystyce i wypowiedziach polityków, [w:] taż, Mówiac przenośnie... Studia o metaforze, Wydawnictwo IBL, Warszawa 1994, s. 136-137.

${ }^{6}$ Por. J. Trzebiński, Narracja jako sposób rozumienia świata, [w:] Praktyki opowiadania, red. B. Owczarek, Z. Mitosek, W. Grajewski, Universitas, Kraków 2001, s. 87-126.

${ }^{7}$ S. Gajda, Społeczna determinacja nazw własnych (tytułów), „Socjolingwistyka” 1987, t. 6, red. W. Lubaś, s. 83.

${ }^{8}$ W. Furman, Tytut, [w:] Stownik terminologii medialnej, red. W Pisarek, Universitas, Kraków 2006, s. 225. 
sujący treść artykułu". Jest to oczywiście pewien model, w praktyce trudno spełnić tego rodzaju wymagania jednocześnie, niekiedy te dwie funkcje - informacyjna i perswazyjna (reklamowa) - wykluczają się lub pozostają w konflikcie ${ }^{10}$.

Nietrudno zauważyć, że metafora, a szczególnie metafora wojny, może dobrze służyć reklamowej funkcji tytułu, zachęcając do lektury. Czy jednak równie dobrze służyć będzie funkcji deskryptywnej?

\section{Metafora wojny w tytułach i w języku biznesu}

Z pewnością metafora wojny jest metaforą dobrze znaną i spotykaną w różnego rodzaju tekstach. Można ją znaleźć często w tytułach tekstów o polityce (np. Wojna na zaproszenia - o relacjach premier Ewy Kopacz i prezesa PiS Jarosława Kaczyńskiego), o sporcie (np. Wojna dwóch światów - o starciu pięściarzy Tomasza Adamka i Artura Szpilki) czy w tytułach książek, by wymienić tylko Wojne polsko-ruska pod flaga biało-czerwona Doroty Masłowskiej.

Czy jednak metafora wojny pasuje do świata biznesu? Jak zauważa Michał Post, metaforyczność w mówieniu o sprawach biznesowych jest czymś powszechnym i naturalnym, gdyż zakłada pojmowanie mniej zrozumiałej dziedziny doświadczenia przy pomocy lepiej zrozumiałej dziedziny. Stąd na przykład personalizacje, służące opisywaniu relacji pomiędzy przedsiębiorstwami na podobieństwo relacji ludzkich, na przykład męsko-damskich ${ }^{11}$.

Z kolei retoryka wojny jest często obecna w opisie zjawisk ekonomicznych. Istnieje wiele pojęć, należących do fachowego języka biznesu, które odwołują się do toposu wojny (który jest w tym wypadku metaforą, nie zaś opisem realnego konfliktu zbrojnego). Są to m.in. wojna cenowa, wojna handlowa czy wojna walutowa. Mówi i pisze się o bataliach (np. o kompetentnego pracownika), o podbijaniu rynków, o kampaniach reklamowych. W wielu firmach o pracownikach zajmujących się sprzedażą mówi się ,siły sprzedaży” (co jest tłumaczeniem angielskiego Sales Force) na podobieństwo ,sił zbrojnych”. Działy firmy nazywa się (od angielskiego division, czyli raczej ,dział”) ,dywizjami”, co przynosi czasem efekt humorystyczny, gdy mówi się nie o „dywizji pancernej”, lecz np. o „dywizji soków”.

\footnotetext{
${ }^{9}$ M. Ślawska, Tytut - najmniejszy tekst prasowy, „Rocznik Prasoznawczy”2008, t. 2, red. T. Mielczarek, s. 125.

${ }^{10}$ M. Kita, Dyskurs prasowy, [w:] Przewodnik po stylistyce polskiej. Style wspótczesnej polszczyzny, red. E. Malinowska, J. Nocoń, U. Żydek-Bednarczuk, Universitas, Kraków 2013, s. 251.

${ }^{11}$ M. Post, TPSA kusi Telię, ale Telia nie chce opuszczać Netii. Kilka uwag na temat metaforycznych i aksjologicznych aspektów języka polskiej prasy gospodarczej, [w:] Język - biznes - media, red. J. Arabski, Wyższa Szkoła Zarządzania Marketingowego i Języków Obcych, Katowice 1999, s. 47-49.
} 


\section{Retoryka wojenna w tytułach z dodatku „Ekonomia \& Rynek”}

Tematem niniejszego tekstu jest wykorzystanie retoryki wojennej w tytułach prasy ekonomicznej. Jako materiał do badań wybrałem dodatek dziennika „Rzeczpospolita” pt. „Ekonomia \& Rynek”, poświęcony, jak sama nazwa wskazuje, tematyce gospodarczej, ekonomicznej i biznesowej. Łącznie analizie poddałem 146 wydań dodatku z końca 2014 i początku 2015 roku. W materiale tym znalazłem ogółem 34 tytuły odwołujące się do retoryki wojny, co wydaje się materiałem wystarczającym do prowadzenia analizy.

Spośród 34 tytułów, w których pojawiało się odwołanie do wojny, wyodrębniłem te, które odnosiły się do wojny jak najbardziej realnej. Tytułów takich było pięć, cztery odnosiły się do wojny rosyjsko-ukraińskiej: Polska finansuje wojnę Putina (Polska poprzez wysokie ceny gazu finansuje rosyjskie działania wojenne na Ukrainie), Jesteśmy w stanie niewypowiedzianej wojny (wywiad z byłym doradcą Kremla Siergiejem Markowem), Nasze koszty wojny na Ukrainie (wpływ wojny na Ukrainie na polską ekonomię: kurs złotego, ceny obligacji, kursy akcji), Wojna pogrąża polskie firmy (o kosztach polskich firm związanych z wojną na Ukrainie). W jednym wypadku chodziło o tzw. cyberwojnę (Firmy informatyczne zarobia na cyberwojnie). Można dyskutować, czy jest to metafora, jednak przyjąłem, że w tym wypadku chodzi o coś bardzo bliskiego typowej wojnie (państwa, broń, konflikt itp.), a więc do analizy metaforyki wojennej służącej opisowi zjawisk niezwiązanych z wojną ten akurat tytuł nadaje się mniej.

Pozostałe tytuły odnosiły się do wojny w sensie metaforycznym. W dwudziestu siedmiu przypadkach tytuły były związane z artykułami o różnym charakterze: od komentarzy odredakcyjnych, przez artykuły problemowe z pierwszej strony dodatku, dwukolumnowe analizy, aż po krótsze artykuły w rodzaju analiz giełdowych. W dwóch pozostałych przypadkach były to tytuły wywiadów $\mathrm{z}$ prezesami firm, będące cytatami z ich wypowiedzi (Jestem gotów na wojnę cenowa; Niemcy wypowiedzieli nam wojnę).

Spośród 29 tytułów włączonych do badanego zbioru najwięcej, bo aż 16, zawierało słowo „wojna”. W czterech pojawiła się „batalia”, w czterech „bitwa”, raz „bitewka” (Bitewka zamiast wojny o LTE), dwa razy „,podbój” (Wsparcie na podbój USA; Polska trampolina do podboju regionu i świata). Pojedyncze tytuły zostały włączone w związku ze słowem, ,wojować” (Mazowsze znów wojuje z rządem), „szturm” (Szturm na wyprzedaże) i „ofensywa” (Ofensywa sieciowych oszustów trwa).

\section{Przymiotniki}

Jeśli chodzi o charakterystykę owej „wojny”, to najczęściej była ona określana jako wojna cenowa (6 przypadków) lub na ceny (2 przypadki). Niekiedy była 
związana z branżą czy typem towarów (paliwowa, herbaciana, internetowa). Dwa razy określenie odnosiło się do natężenia konfliktu (ostra).

\section{O co ta wojna? Jakimi środkami?}

Zwykle wojna była opisywana jako wojna o konkretne zasoby, a więc wojna w pewien sposób racjonalna. Chodziło o paczki, tj. o rynek usług związanych z dostarczaniem przesyłek (Kurierzy ruszaja na wojnę o paczki), o pocztowe przetargi (Nowa batalia o pocztowe przetargi), o energetykę (Europejska batalia o energetykę odnawialna), o markę Tiger (Ostra wojna o Tigera nie zniechęcita do zakupów), o konkretną firmę (Krajobraz po bitwie o Kompanię Węglowa), o polisy dla firm (Cenowa wojna o polisy dla firm), o lotnisko Heathrow (Bitwa o Heathrow czyli lotnicza konsolidacja), o odnawialne źródła energii, czyli OZE (Batalia o OZE trwa), o OFE (Bitwa o OFE: Polacy kontra rząd), o LTE (Bitewka zamiast wojny o LTE).

Orężem w walkach były najczęściej ceny (Ostra wojna sieci na ceny właśnie się rozkręca), rzadziej inne rodzaje broni: listy (Nierówna bitwa na listy) czy marki (Wojna na marki czyli rewolucja w wędlinach).

W zawartym w badanych tytułach opisie cech, celów owych ,wojen”, a także używanych w nich oręży nacisk nie jest położony na sam przebieg konfliktu, lecz raczej na zrozumienie natury konfliktu - czego dotyczy, co jest jego przedmiotem.

\section{Czasowniki - działania}

Przebieg wojny był opisywany rzadziej; jako czasowniki pojawiły się leksemy odnoszące się do bycia gotowym do wojny (Jestem gotów na wojnę cenowa), wypowiadania jej (Niemcy wypowiedzieli nam wojnę), ruszania na wojnę (Kurierzy ruszają na wojne o paczki) bądź intensyfikowania konfliktu, gdzie - co ciekawe - pojawiło się zgoła niemilitarne, może nawet nieco frywolne ,rozkręcanie", które lepiej pasowałoby np. do zabawy, zaś tu ujawniało pewien dystans do militarnej metafory (Ostra wojna sieci na ceny właśnie się rozkręca).

\section{Kto walczy?}

W wielu wypadkach tytuły nie przesądzały, kto jest stroną sporu, akcentując raczej jego przedmiot (np. Wojna na marki czyli rewolucja w wędlinach czy wojny o LTE, OFE, markę Tiger itd.). Taka sytuacja miała miejsce w mniej więcej dwóch trzecich przypadków. Ilustruje to opisany wyżej konflikt pomiędzy funkcją informacyjną i perswazyjną tytułów: niedopowiedzenie (czyli niepełna realizacja funkcji informacyjnej) może jednocześnie zachęcać do lektury - czytelnicy, zastanawiając się, kto też toczy np. wojnę o LTE, mogli zainteresować się tekstem.

Przypadki, kiedy tytuł przesądzał, kto jest stroną konfliktu, można podzielić na dwie kategorie: a) firmy toczą wojnę między sobą, b) firmy lub instytucje walczą z władzami. 
a) Firmy walczą między sobą

Tutaj można wymienić przypadki, gdy w wojnie uczestniczą dwie konkretne firmy, określone w tytule (Mokate kontra Posti czyli polska wojna herbaciana), jedna konkretna firma walczy z grupą firm, niewymienionych z nazwy (Internetowa wojna cenowa Orange z kablówkami) bądź walczące firmy są opisane przez ogólne określenie, np. sieci, a czytelnik nie dowiaduje się z samego tytułu, o jakie „sieci” może chodzić (Ostra wojna sieci na ceny właśnie się rozkręca), dopiero lektura lidu wyjaśniała, że chodzi o sieci handlowe: super- i hipermarkety (Sklepy coraz mocniej rywalizuja tańszymi produktami. Dla klientów trudno o lepsza wiadomość).

b) Firmy/instytucje walczą z władzami

Obok wojen rozgrywających się w świecie biznesu są i takie, gdzie „linie frontu" są wytyczone wewnątrz społeczeństwa. Zwykle po jednej stronie jest rząd lub agenda rządowa. Albo jakaś konkretna firma walczy z instytucją rządową, niekoniecznie narodową, np. z Parlamentem Europejskim (Europejski parlament na wojnie z Google), albo też z konkretnym państwem, jak w przypadku firmy Raben (Niemcy wypowiedzieli nam wojne cenowa - tytuł wywiadu z prezesem działającej w Polsce firmy transportowej). Walczyć mogą też mieszkańcy kraju ze swoim rządem (Bitwa o OFE: Polacy kontra rząd) bądź jeden ośrodek władzy z innym, np. województwo z rządem krajowym (Mazowsze znów wojuje z rządem).

Takie ujmowanie sporów nie jest bynajmniej zaskakujące. Jak pisze cytowany już tu Michał Post, „, języku prasy biznesowej instytucje gospodarcze mają charakter istot ludzkich”, zaś „,metafora «instytucja gospodarcza to istota ludzka» jest jedyną z najczęściej występujących w tekstach biznesowych"12.

W świetle opisanych wyżej metafor działalność biznesowa jest przedstawiona jako wojna, w której ścierają się między sobą firmy-państwa albo też firmy-państwa po prostu z państwami (rządami, narodami). Paradoksalnie czytelnicy, a więc najczęściej konsumenci, nie są w te wojny zaangażowani, niekiedy nawet mogą oni na wojnie zyskiwać (por. podtytuł tekstu o wojnie sieci handlowych na ceny, cytowany wyżej).

\section{Czas}

$\mathrm{W}$ analizowanych tytułach silnie akcentowany jest aspekt temporalny - zbliżanie się wojny, jej początek, trwanie, wreszcie koniec. Wśród dwudziestu dziewięciu badanych tytułów można odnaleźć wszystkie etapy konfliktu: zbliżanie się (Wojna cenowa na horyzoncie), moment oficjalnego rozpoczęcia konfliktu (Niemcy wypowiedzieli nam wojne), początek działań wojennych (Kurierzy ruszają na wojnę o paczki), eskalację walk (Ostra wojna sieci na ceny właśnie się

\footnotetext{
${ }^{12}$ M. Post, dz. cyt., s. 49.
} 
rozkręca), epizody wojenne (Nierówna bitwa na listy; Nowa batalia o pocztowe przetargi), trwanie konfliktu (Batalia o OZE trwa; Ofensywa sieciowych oszustów trwa), wreszcie jego możliwe zakończenie (Czy to koniec wojny cenowej).

Wojna w biznesie: mapa percepcyjna

Metafora wojny w analizowanych tytułach jest całościowym - choć opisywanym wycinkowo w poszczególnych tytułach - obrazem. Występuje tam komplet składników, konstytuujących ten obraz, a więc:

- walczący wrogowie (firmy między sobą, firmy-rządy; zwykle dwóch antagonistów);

- zasoby, dobra pożądane: rynek, marki lub przychody (paczki, przetargi, energetyka, polisy dla firm, Heathrow, OZE, LTE, skup obligacji);

- oręż (ceny, marki);

- czas: wojna się zbliża, wybucha, trwa (epizody - bitwy, batalie), kończy się, rozpoczyna się znowu.

Można się z drugiej strony zastanawiać, czego w tym obrazie brakuje. Nie ma armii, ofiar i zniszczeń. Wojna ta nie ma charakteru wojny totalnej. Są to konflikty - można powiedzieć - lokalne, niezaburzające normalnego funkcjonowania społeczeństw. Mimo wojny, życie toczy się dalej. Widać to np. w tytule Ostra wojna o Tigera nie zniechęciła do zakupów. Firmy walczą, a ludzie kupują, nie przejmując się konfliktem. Wojna taka niekoniecznie wyniszcza walczące strony - może się też wiązać z korzyściami dla któregoś z uczestników konfliktu, np. PZU rośnie pomimo wojny cenowej. Jest to więc wojna w pewnym sensie oswojona, oddramatyzowana, opisywana z punktu widzenia niezaangażowanej w konflikt „milczącej większości”, z dystansu przyglądającej się walczącym stronom, niekiedy odnoszącej z tego wymierne korzyści (np. z wojny cenowej).

\section{Biznes jako wojna: metafora, prawda, działanie}

Można więc zastanawiać się, jaki wpływ na postrzeganie działalności biznesowej ma opisywanie jej (w tytułach) przy użyciu metafory wojny. Jak piszą Lakoff i Johnson:

metafory mogą nam stwarzać pewne realia, zwłaszcza realia społeczne. Metafora może więc wskazywać przyszłe działania. Takie działania będą oczywiście pasować do metafory. To z kolei zwiększy wpływ metafory na koherencję doświadczeń. W tym sensie metafory stają się proroctwami, które się same spełniają ${ }^{13}$.

${ }^{13}$ G. Lakoff, M. Johnson, dz. cyt., s. 184. 
Autorzy ci analizują w swojej książce przypadek posłużenia się metaforą wojny do opisu kryzysu naftowego, kiedy to prezydent John Carter ogłosił „stan moralnie odpowiadający wojnie”: „Metafora «wojny» uwypuklała pewne realia, a ukrywała inne. Nie była po prostu sposobem patrzenia na rzeczywistość, lecz uprawomocniała zmianę polityki oraz podejmowanie akcyj politycznych i ekonomicznych"14.

W podsumowaniu powyższych analiz tytułów zawierających metaforę wojny w odniesieniu do aktywności biznesowej można pokusić się o kilka uwag.

1. Jeśli jedną z funkcji tytułu jest zachęcenie do lektury, to tytuły operujące retoryką militarną prawdopodobnie aktywizują czytelników i skłaniają ich do lektury przez dramatyzację opisywanych konfliktów. Niedopowiedzenie, deficyt informacji wymagają wczytania się w tekst, a przynajmniej w lid, wyjaśniający niektóre szczegóły konfliktu.

2. Zarazem $z$ tego samego powodu tytuły takie gorzej wypełniają funkcje informacyjne względem treści artykułów, a często mogą być wręcz mylące, sugerując, że konflikt o podłożu ekonomicznym ma charakter zbrojny - przynajmniej do momentu, gdy czytelnik zorientuje się, że to metafora. Rozpoznanie takie nie musi być jednak automatyczne wobec faktu, że jednocześnie na tych samych łamach inny artykuł może opisywać realny konflikt zbrojny.

3. Patrząc z innego punktu widzenia, można jednocześnie zauważyć, że metafora wojny może w wielu przypadkach ułatwiać zrozumienie i przyswojenie opisywanych konfliktów, upraszczając skomplikowaną materię sporów prawnych czy rywalizacji o charakterze marketingowym do poziomu umożliwiającego percepcję tych sporów przez czytelnika. Ulokowanie ich w obrębie znanego schematu percepcyjnego - wojny - może rekompensować uproszczenie, z jakim jest to związane.

4. W skali makro postrzeganie konfliktów i rywalizacji prawnej bądź ekonomicznej w kategoriach wojny może przynosić skutki negatywne. Może prowadzić do antagonizowania uczestników sporów, zaostrzając konflikty, pokazując bardziej niż w istocie kosztowne skutki braku wygranej i wymuszając tym samym na nich bardziej radykalne działania. Jednocześnie poprzez taki właśnie metaforyczny opis konfliktu usuwane są z pola widzenia bardziej łagodne, kompromisowe rozwiązania, trudniejsze do przyjęcia, gdy myśli się o sporze jako o wojnie, a o rywalu jako o przeciwniku.

\section{Bibliografia}

Dobrzyńska T., Metafory wartościujące w publicystyce i wypowiedziach polityków, [w:] taż, Mówiąc przenośnie... Studia o metaforze, Wydawnictwo IBL, Warszawa 1994, s. 135-149.

Furman W., Tytut, [w:] Słownik terminologii medialnej, red. W Pisarek, Universitas, Kraków 2006, s. 225.

${ }^{14}$ Tamże. 
Gajda S., Społeczna determinacja nazw własnych (tytułów), „Socjolingwistyka” 1987, t. 6, red. W. Lubaś, s. 79-89.

Kita M., Dyskurs prasowy, [w:] Przewodnik po stylistyce polskiej. Style wspótczesnej polszczyzny, red. E. Malinowska, J. Nocoń, U. Żydek-Bednarczuk, Universitas, Kraków 2013, s. 199-288.

Lakoff G., Johnson M., Metafory w naszym życiu, przeł. T. Krzeszowski, PIW, Warszawa 1988.

Maciuszek J., Metafora jako forma komunikacji perswazyjnej, [w:] Sztuka perswazji, red. R. Garpiel, K. Leszczyńska, Zakład Wydawniczy „Nomos”, Kraków 2004, s. 115-130.

Post M., TPSA kusi Telię, ale Telia nie chce opuszczać Netii. Kilka uwag na temat metaforycznych i aksjologicznych aspektów języka polskiej prasy gospodarczej, [w:] Język-biznes - media, red. J. Arabski, Wyższa Szkoła Zarządzania Marketingowego i Języków Obcych, Katowice 1999, s. 47-54.

Ślawska M., Tytut - najmniejszy tekst prasowy, „Rocznik Prasoznawczy” 2008, t. 2, red. T. Mielczarek, s. 117-126.

Trzebiński J., Narracja jako sposób rozumienia świata, [w:] Praktyki opowiadania, red. B. Owczarek, Z. Mitosek, W. Grajewski, Universitas, Kraków 2001, s. 87-126.

\section{Marek Kochan}

\section{Business as War. The Rhetoric of War in the Headlines of the Business Press}

\section{(Summary)}

The topic of this article is the usage of the metaphor of war in the headlines of articles from Ekonomia\& Rynek (Economy\&Market), a division of the Rzeczpospolita daily, devoted to business issues. In order to establish the frame of the analysis, the author discusses the cognitive functions of metaphors (using G. Lakoff and M. Johnson's study Metaphors we live by and other works devoted to the subject), the functions of the headlines in relation to the text and the usage of the rhetoric of war in business language. The majority of the paper is dedicated to a detailed analysis of headlines using the metaphor of war found in the examined sample (a total of 34 in 146 editions of the Ekonomia\&Rynek section). In the article, the main elements of these metaphors are described: commonly used words, parties to the conflict, the nature of the conflict, the temporal dimension etc. In the final section of the text the author explores the issue of the potential results of the usage of metaphor of war: both for the readers and the institutions engaged in the conflicts.

Key words: war rhetoric, headlines, business language, metaphors. 